\title{
Mutations Associated with Resistance-Breaking Isolates of Beet necrotic yellow vein virus and Their Allelic Discrimination Using TaqMan Technology
}

\author{
R. Acosta-Leal and C. M. Rush
}

Texas Agriculture Experimental Station, Amarillo. Accepted for publication 12 October 2006.

\begin{abstract}
Acosta-Leal, R., and Rush, C. M. 2007. Mutations associated with resistance-breaking isolates of Beet necrotic yellow vein virus and their allelic discrimination using TaqMan technology. Phytopathology 97:325330.

Genetic resistance in sugar beet (Beta vulgaris) to Beet necrotic yellow vein virus (BNYVV), which causes the disease rhizomania, is conferred by the single dominant gene $R z 1$. However, since $2002, R z 1$ cultivars grown in the Imperial Valley of California have been increasingly damaged by a new strain of BNYVV. Viral RNA 3 was extracted from asymptomatic and symptomatic sugar beets and, after amplification and sequencing of a region including the p25 cistron, two polymorphic sites, A67V and D135E, associated with the capability of the virus to overcome resistance were identified. Using the real-time reverse transcriptionpolymerase chain reaction allelic discrimination technique, TaqMan probes
\end{abstract}

ABSTRACT designed to detect the responsible nucleotide substitutions permitted the differentiation between wild type (WT) and resistance-breaking (RB) isolates. This method also allowed easy detection of mixed infections by giving a heterozygous call, which was verified by DNA sequencing of individual clones. The capability of this technology to typify numerous isolates facilitated the analysis of the spatial distribution of virus haplotypes in the field. Thus, RB variants were mostly baited from yellow strips with high incidence of rhizomania, whereas WT variants predominated in the surrounding green areas. Mixed infections were found mainly in green areas and transitional zones. The predominance of the RB isolates in yellow strips suggests that they have gained fitness in $R z 1$ cultivars and will eventually become the dominant haplotype.

Additional keywords: benyvirus, genotyping, population structure, quasispecies, resistance durability, soilborne disease, virus ecology.
Beet necrotic yellow vein virus (BNYVV) is the causal agent of rhizomania, a sugar beet disease first reported in Italy in 1958 (3), which now has a worldwide distribution. Plants with rhizomania exhibit florescent yellow foliage, profuse proliferation of lateral rootlets, root necrosis, and drastic reduction in taproot development. The spatial distribution of the disease is typically in irregularly shaped spots or strips randomly scattered throughout the field $(20,29)$. Since its first report in North America in 1984 (7), BNYVV has been detected in all major production regions of the United States (20). Despite its broad distribution, damage caused by this virus has been ameliorated during the last 15 years by the introgression of the dominant $R z l$ resistance gene into regionally adapted cultivars. However, in 2002, a number of sugar beet fields planted with $R z l$ cultivars in the Imperial Valley of California were observed with severe symptoms of rhizomania. Pathogenicity tests, using infested soil as inoculum, suggested that resistance-breaking (RB) variants of BNYVV had emerged in this region (15).

BNYVV is a rod-shaped multipartite RNA virus transmitted by the plasmodiophorid Polymyxa betae. RNA 1 and 2 encode the essential elements for replication, assembly, movement, and suppression of gene silencing, whereas RNA 3 and 4 encode proteins more directly involved in pathogenesis and vector transmission $(18,19,24,26)$. In addition, some European and Japanese isolates also possess a genomic RNA 5 that encodes a single polypeptide and exacerbates symptom severity in synergy with RNA 3. However, the suspected RB isolates from California do not contain

Corresponding author: C. M. Rush; E-mail address: cm-rush@tamu.edu

DOI: 10.1094/PHYTO-97-3-0325

(c) 2007 The American Phytopathological Society the RNA 5 (15), and consequently it does not account for the emergence of the disease.

BNYVV infection is usually confined to the root system. After initial infection of a root hair cell, the virus moves cell to cell and then long distance through the xylem vessels (6), which is in contrast to most plant viruses that utilize the phloem for vascular translocation (26). However, distribution of the virus in infected roots is typically limited (13). The resistance mechanism governed by $R z 1$ is still unclear; however, it is characterized by a 10 - to 20-fold reduction in virus concentration in the taproot of mature plants without significant differences in the content of virus in the rootlets, which suggests that $R z 1$ might act during virus replication and/or virus vascular translocation $(10,23,25)$.

The predominant genomic determinant for rhizomania development is the p 25 protein encoded by RNA 3 (25). The p25 protein is suspected to operate as a nucleo-cytoplasmic shuttle based on the presence of a nuclear localization signal in the $\mathrm{N}$-terminal region and a nuclear export sequence in the C-terminal part (27). Whether these properties of p25 are related to the development of rhizomania is unknown. On the other hand, sequences, but not coding products of RNA 3, facilitate the vascular translocation of BNYVV in mechanically inoculated leaves of Beta macrocarpa (14). Based on these observations, we decided to explore the sequences of BNYVV RNA 3 in relation to its capability to cause rhizomania in $R z l$ cultivars of sugar beets.

\section{MATERIALS AND METHODS}

Field isolates. BNYVV rarely infects the upper part of the plant, but root-infected plants normally develop generalized chlorosis during maturation, which facilitates identification of plants with rhizomania (20). Thus, plants suspected of being 
severely diseased were spotted, and damaged roots were collected from five sugar beet fields around the Imperial Valley during the summer of 2005. These fields were planted with sugar beet cvs. Phoenix and Beta 4430 that possess the Rzl gene. A composite sample derived from 5 to 10 asymptomatic roots was also collected from one of these fields with the intent of using it as negative control for virus detection and quantification. A BNYVV isolate collected from a field planted with a susceptible sugar beet hybrid from Salinas, CA (provided by R. Lewellen, U.S. Department of Agriculture-Agricultural Research Service, Salinas, CA) was used as a wild type (WT) reference.

Total RNA extractions from root tissue. RNA was extracted from symptomatic rootlets or asymptomatic taproot tissue with the RNAqueous-Mini kit (Ambion Inc., Austin, TX) with the following modifications in the protocol: plant tissue $(0.1$ to $0.2 \mathrm{~g})$ was frozen with liquid $\mathrm{N}_{2}$, powdered inside a $2.0-\mathrm{ml}$ microfuge tube, and resuspended in $1.5 \mathrm{ml}$ of the Ambion Lysis/Binding Solution. The supernatant obtained after centrifugation $(16,000 \times$ $g$ for $10 \mathrm{~min}$ ) was mixed with $1.5 \mathrm{ml}$ of $64 \%$ ethanol and passed through the glass fiber filter using a vacuum manifold. The filter was dried by centrifugation $(16,000 \times g$ for $1 \mathrm{~min})$ and washed with $1.5 \mathrm{ml}$ of Ambion Sol. \#1 using the vacuum manifold and then with $2.0 \mathrm{ml}$ of Ambion Sol. \#2/3 in the same manner. At the end, the filter was dried again by short centrifugation and transferred to a $1.7-\mathrm{ml}$ microfuge tube where the RNA was eluted in $50 \mu \mathrm{l}$ of preheated $\left(80^{\circ} \mathrm{C}\right)$ Ambion Elution Solution during a centrifugation at $16,000 \times g$ for $30 \mathrm{~s}$.

Reverse transcription-polymerase chain reaction (RT-PCR), cloning, and sequencing. First-strand cDNA was synthesized with the Omniscript reverse transcriptase kit (Qiagen Inc., Valencia, CA) according to manufacturer recommendations. Total RNA $(0.5 \mu \mathrm{g})$ was incubated with $1.0 \mu \mathrm{g}$ of oligo-dT $\mathrm{T}_{12-18}$ primer at $65^{\circ} \mathrm{C}$ for 5 min before cDNA polymerization. PCR was performed separately using Platinum Taq high-fidelity polymerase (Invitrogen, Inc., Carlsbad, CA) and $5.0 \mu \mathrm{l}$ of the reverse transcription products. Forward, F-29, and reverse, R-30, primers (Table 1) were added at concentrations of $0.5 \mu \mathrm{M}$ each, and the rest of the reagents were incorporated at concentrations recommended by the manufacturer. The PCR was run for 25 cycles of denaturing at $94^{\circ} \mathrm{C} / 30 \mathrm{~s}$, annealing at $55^{\circ} \mathrm{C} / 30 \mathrm{~s}$, and extending at $68^{\circ} \mathrm{C} / 1.5 \mathrm{~min}$. Then, the amplified DNA, composed mainly of the expected 1,015-bp fragment, was cleaned using the QIAquick kit (Qiagen Inc.), quantified by spectrometry, and submitted for sequencing. Some of these amplicons were inserted into the pCR-Blunt (Invitrogen, Inc.) vector, and individual clones were screened and sequenced to analyze the genetic composition of the infecting populations. DNA sequencing was conducted by the Institute of Plant Genomics and Biotechnology at Texas A\&M University using BigDye version 3.1 and the ABI 3100 capillary sequencer. Chromatograms were analyzed with ABI Sequencing Analysis Software version 5.2, and further sequence analyses were performed using the DNAstar version 4.0 package (Dnastar, Inc., Madison, WI).

Real-time RT-PCR allelic discrimination. Based on the polymorphic sites found in the p25 cistron of BNYVV RNA 3, allelic discrimination primers and $3^{\prime}$ minor groove binder Taqman probes $(1,16)$ were designed, using Primer Express version 2.0. (Applied Biosystems, Foster City, CA). Two sets of primersprobes were developed: one to target the polymorphisms at codons 67-68, and the other to target the single nucleotide polymorphism found at codon 135 (Tables 1 and 2). The consensus sequences of the WT BNYVV isolate Clx and the RB isolate Mag were used in the design of the mentioned oligonucleotides. Realtime protocols were optimized for one- or two-step RT-PCR. The

TABLE 1. Primers and Taqman probes used to amplify the Beet necrotic yellow vein virus p25 region (RNA 3) or for real-time polymerase chain reaction (PCR) allelic discrimination (AD) assays ${ }^{\mathrm{a}}$

\begin{tabular}{llllc}
\hline Assay (target) & Oligo name & Orientation & \multicolumn{1}{c}{ Sequence $\left(5^{\prime} \rightarrow 3^{\prime}\right)$} & $\begin{array}{c}\text { Position } \\
\text { (accession no. NC 003516) }\end{array}$ \\
\hline Regular PCR (p25) & F-29 & Forward & TTAATCCAAGTACCTCGTCT & $108-127$ \\
& R-30 & Reverse & TTGAAATTGTGATAACTCTAA & $1121-1101$ \\
AD (codons 67-68) & NY05F & Forward & CAATAATACTAAACGCATAAGGTTCGT & $603-630$ \\
& NY05R & Reverse & CATAACATTACTCTACATAAGGCACGAA & $695-668$ \\
& CIV1 & FAM probe & TTGTGTGtTctTCATGG & $637-653$ \\
AD (codon 135) & Clx1 & VIC probe & TGTGTGcTtgTCATG G & $638-653$ \\
& NY06F & Forward & CGTCATCCACTATGATCGTGTTC & $804-826$ \\
& NY06R & Reverse & AAGACAGTCGTGAAATCTACAACTTCA & $881-855$ \\
& CIV2 & FAM probe & ACACACTGAgGGTT & $840-854$ \\
& Clx2 & VIC probe & CTTACACACTGAtGGTTT & $837-854$ \\
\hline
\end{tabular}

a The probes for real-time PCR allelic discrimination were 5'-end labeled with 6-carboxyfluoroscein (FAM) or VIC dye, and 3'-end linked to a minor groove binder-quencher molecule (the polymorphic nucleotide is indicated by a lowercase letter).

TABLE 2. Polymorphic regions in the p25 cistron of Beet necrotic yellow vein virus RNA 3 used to discriminate between resistance-breaking and wild-type isolates collected from Salinas and Imperial Valleys of California in 2005

\begin{tabular}{|c|c|c|c|c|}
\hline Source ${ }^{a}$ & Isolate & Codons 66-69 & Codons 134-136 & Motif $^{b}$ \\
\hline$r z 1 /$ sym & Sal & 640-UGU GCU UGU CAU & 844-ACU GAU GGU & $\mathrm{ACD}$ \\
\hline$R z 1 /(-)$ & $(-) \operatorname{civ}$ & $----C_{-} \quad--$ & ------- & ALD \\
\hline$R z 1 / \mathrm{sym}$ & $\begin{array}{l}\text { Tae } \\
\text { Mag } \\
\text { Spr } \\
\text { DWe } \\
\text { Tam }\end{array}$ & $\begin{array}{llll}--- & -U- & - & -- \\
--- & -U- & C U- & -- \\
--- & -U- & C U- & -- \\
--- & -U- & C U- & -- \\
--- & -U- & C U- & ---\end{array}$ & $\begin{array}{lll}--- & -G & -- \\
--- & --G & --- \\
--- & --G & -- \\
--- & --G & --- \\
--- & --G & ---\end{array}$ & $\begin{array}{l}\text { VCE } \\
\text { VLE } \\
\text { VLE } \\
\text { VLE } \\
\text { VLE }\end{array}$ \\
\hline
\end{tabular}

${ }^{a}$ The genotype/phenotype of the sampled sugar beets was homozygous recessive ( $\left.r z 1\right)$, homozygous or heterozygous dominant (Rz1), symptomatic (sym), or asymptomatic (-). The field sources of wild-type isolates were a composite sample (three to five plants) collected from susceptible cultivars of sugar beets developing symptoms of rhizomania $(r z 1 / \mathrm{sym})$ in Salinas Valley, or a composite sample of asymptomatic resistant plants $[R z 1 /(-)]$ cultivated in the Imperial Valley. Resistance-breaking isolates, on the other hand, were collected from five fields cultivated with resistant cultivars and showing severe symptoms of rhizomania $(R z 1 / \mathrm{sym})$.

${ }^{\mathrm{b}}$ The described mutations, determined by DNA sequencing of high-fidelity amplicons, caused amino acid substitutions at positions 67,68 , and 135 giving distinctive wild-type $\left(\mathrm{A}_{67} \mathrm{C}_{68} \mathrm{D}_{135}\right.$ or $\left.\mathrm{A}_{67} \mathrm{~L}_{68} \mathrm{D}_{135}\right)$ and resistance-breaking $\left(\mathrm{V}_{67} \mathrm{C}_{68} \mathrm{E}_{135}\right.$ or $\left.\mathrm{V}_{67} \mathrm{~L}_{68} \mathrm{E}_{135}\right)$ motifs. 
reacting components included in the TaqMan One-Step were the following: RT-PCR Master Mix Reagents Kit (Applied Biosystems) at concentrations recommended by the manufacturer, $50 \mathrm{nM}$ FAM-labeled probe, $100 \mathrm{nM}$ VIC-labeled probe, $300 \mathrm{nM}$ of each primer, and $2.0 \mu$ of total RNA preparation $(<1$ $\mu \mathrm{g})$ per $25-\mu \mathrm{l}$ reaction. In the two-steps RT-PCR protocol, first-strand cDNA was synthesized as described in the previous section and the PCR was carried out using the TaqMan Universal PCR Master Mix supplied by the same company. Amounts of probes and primers were the same as in the one-step protocol, but $2.5 \mu \mathrm{l}$ of cDNA preparation was added to each $25-\mu \mathrm{l}$ reaction instead of total RNA. The thermocycling and data analysis were performed with an ABI Prism 7000 (Applied Biosystems) instrument using the universal PCR or RT-PCR parameters.

Spatial distribution of virus haplotypes in the field. The spatial distribution of rhizomania in the Imperial Valley is very conspicuous but atypical, consisting of adjacent rows of symptomatic infected plants in irregularly spaced strips throughout the field $(15,20)$. Rhizosphere soil samples were collected from several fields during 2003 and 2005. Samples were collected from the middle of symptomatic strips in the field and from asymptomatic areas adjacent to the strips. Each sample, approximately $200 \mathrm{~g}$ of soil taken from the rhizosphere of individual plants, was collected at 30-m intervals along 300-m row, making a total of 10 samples per row. Then, a greenhouse assay was conducted to bait BNYVV from the soil samples using the resistant sugar beet $\mathrm{cv}$. Beta 46519. Around 12 weeks after planting, total RNA was extracted from root tissue from a total of 56 bait plants. The single-plant RNA isolates obtained from those BNYVV-infected plants were stored at $-80^{\circ} \mathrm{C}$ until they were genotyped by consensus cDNA sequencing and/or real-time allelic discrimination assays.

\section{RESULTS}

Identification of polymorphism in RNA 3 p25 cistron. The predicted amino acid sequences of BNYVV in the p25 region revealed that all field isolates obtained from severely diseased plants carrying the $R z 1$ gene exhibited the $\mathrm{V}_{67} \mathrm{~L}_{68} \mathrm{E}_{135}$ or $\mathrm{V}_{67} \mathrm{C}_{68} \mathrm{E}_{135}$ motif, whereas the isolate from the Salinas Valley (susceptible plants with rhizomania) and the isolate from asymptomatic $R z 1$ plants from the Imperial Valley encoded an $\mathrm{A}_{67} \mathrm{C}_{68} \mathrm{D}_{135}$ or $\mathrm{A}_{67} \mathrm{~L}_{68} \mathrm{D}_{135}$ motif, respectively (Table 2). Among the $\mathrm{RB}$ isolates, haplotypes carrying $\mathrm{V}_{67} \mathrm{~L}_{68} \mathrm{E}_{135}$ were more abundant than haplotypes encoding the $\mathrm{V}_{67} \mathrm{C}_{68} \mathrm{E}_{135}$ amino acid substitutions. The former motif has been found only in the Imperial Valley of California, whereas the later has been reported also from Spain (22). Given that the amino acids, cysteine or leucine, at position 68 seem to be more ambiguous for differentiation between these pathotypes, we consider $\mathrm{V}_{67} \mathrm{E}_{135}$ as the signature for $\mathrm{RB}$ variants of BNYVV from the Imperial Valley, as opposed to the WT motif $\mathrm{A}_{67} \mathrm{D}_{135}$. Collateral studies in our lab indicate that the WT $\mathrm{A}_{67} \mathrm{C}_{68} \mathrm{D}_{135}$ amino acid motif prevails in several sugar beet production regions throughout the United States, and has been present for at least 16 years (data not shown).

Discrimination between WT and RB isolates using Taqman probes. Both one- and two-step RT-PCR protocols were able to discriminate between WT and RB BNYVV isolates, based on their nucleotide polymorphisms at 67-68 and 135 codons of the p25 cistron (Fig. 1). Given its simplicity and lower risk of crosscontamination, the one-step RT-PCR protocol was adopted as the standard procedure to analyze most of the samples included in this study. This approach also allowed the detection of samples with putative RB and WT mixed infections. Viral RNA targets carrying as low as a single nucleotide mismatch for both probes always rendered an undetermined call, which made this technique
RNA template (codons 67-68)

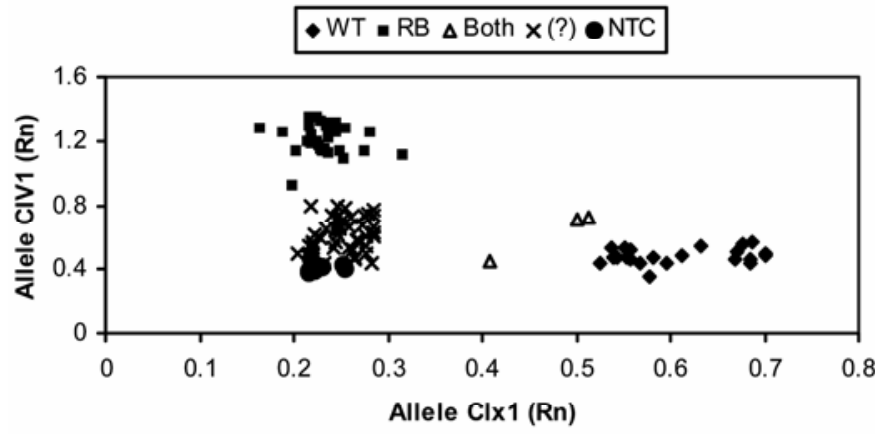

cDNA template (codons 67-68)

$\bullet \mathrm{WT} \bullet \mathrm{RB} \times(?) \bullet \mathrm{NTC}$

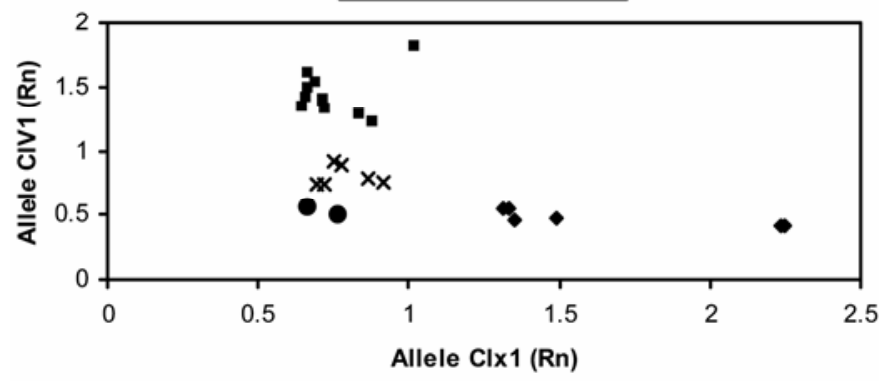

RNA template (codon 135)

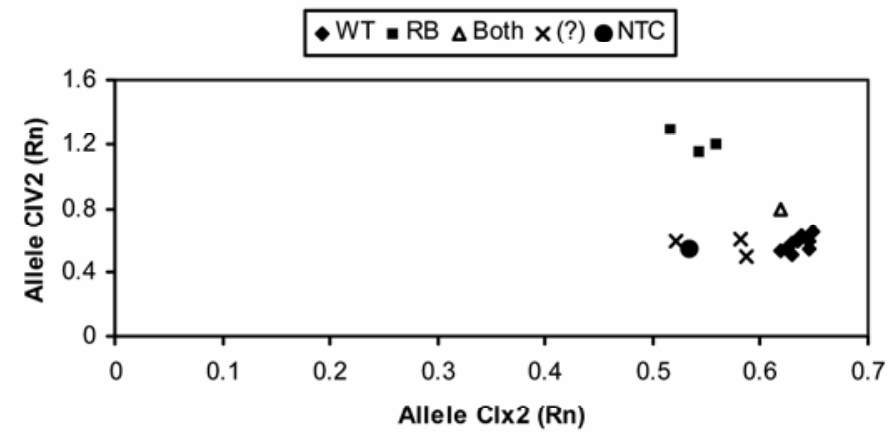

cDNA template (codon 135)

$\bullet$ WT $\because \mathrm{RB} \triangle \mathrm{Both} \bullet \mathrm{NTC}$

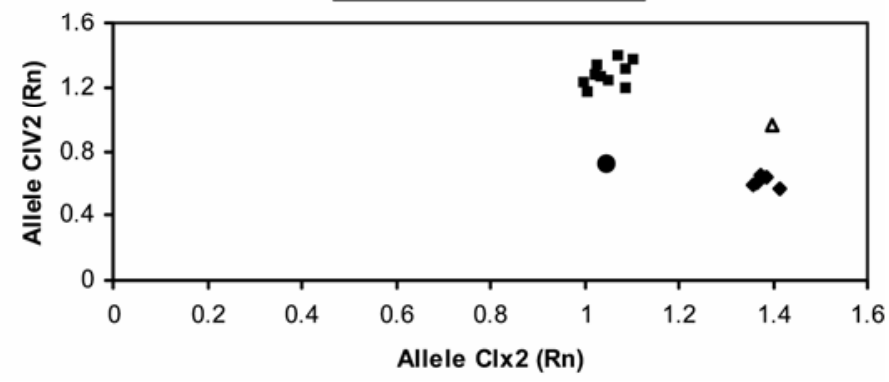

Fig. 1. Fluorescent intensity (Rn) plots for FAM- versus VIC-labeled probes obtained after real-time reverse transcription-polymerase chain reaction allelic discrimination assays. The FAM probes were designed to detect the resistance-breaking (RB) CIV1 (at codon position 67-68) or CIV2 (at codon position 135) alleles, whereas the VIC probes were designed to detect the wild type (WT) Clx1 (positions 67-68) or Clx2 (position 135) alleles. Samples that produced a significantly higher Rn than the nontemplate control (NTC) were identified as WT, RB, or mixed infected (Both) depending of the kind of emitted fluorescence (FAM or VIC). Otherwise, they were considered undetermined (?). These discrimination assays were tested using total RNA extracted from roots (upper plots) or single-strand cDNA (lower plots) as templates. 
highly specific to detect only sequences with perfect annealing to the designed TaqMan probes.

Association between the spatial distribution of rhizomania in the field and the virus genotype. A total of 36 virus isolates were baited from 56 soil samples collected during 2003 and 2005 from yellow strips and adjacent green areas in the field. Isolates were genotyped by cDNA sequencing and/or real-time RT-PCR allelic discrimination assays. Most of the isolates baited from yellow strips (11 out of 13) carried the $R B V_{67} L_{68} E_{135}$ motif. This motif was predicted only by allelic discrimination assays in isolates VB7 and VE8, and by both approaches in the rest of the eleven isolates (Table 3). The samples collected during 2005 exhibited the highest rhizomania- $\mathrm{V}_{67} \mathrm{~L}_{68} \mathrm{E}_{135}$ association. By contrast, only 2 out of 22 isolates collected from the surrounding green areas, R158D5 and R158E4, were predicted by the allelic

TABLE 3. Relationship between the source of the Beet necrotic yellow vein virus field isolate and its p 25 motif determined by DNA sequencing and/or real-time reverse transcription-polymerase chain reaction (RT-PCR) allelic discrimination assays

\begin{tabular}{|c|c|c|c|c|c|}
\hline \multirow[b]{2}{*}{ Soil source } & \multirow[b]{2}{*}{ Year } & \multirow[b]{2}{*}{ Isolate } & \multirow[b]{2}{*}{$\begin{array}{l}\text { Motif }(67- \\
68,135)^{\mathrm{a}}\end{array}$} & \multicolumn{2}{|c|}{$\begin{array}{c}\text { Allelic } \\
\text { discrimination }^{\mathrm{b}}\end{array}$} \\
\hline & & & & $\begin{array}{c}\text { Codons } \\
67-68\end{array}$ & $\begin{array}{c}\text { Codon } \\
135\end{array}$ \\
\hline \multirow[t]{22}{*}{$\begin{array}{l}\text { Green strips } \\
\text { (mostly asympto- } \\
\text { matic plants) }\end{array}$} & 2003 & R156A1 & ALD & (?) & D \\
\hline & & R156A7 & - & $\mathrm{AC}$ & D \\
\hline & & R156C5 & ALD & $(?)$ & $\mathrm{D}$ \\
\hline & & R156D8 & - & (?) & $\mathrm{D}$ \\
\hline & & R158D5 & - & VL & $\mathrm{E}$ \\
\hline & & R158D6 & ALD & VL & $D+E$ \\
\hline & & R158E4 & - & VL & $\mathrm{E}$ \\
\hline & & VC10 & ALD & $(?)$ & $\mathrm{D}$ \\
\hline & & VD4 & - & $(?)$ & $\mathrm{D}$ \\
\hline & & VF1 & $\mathrm{ACD}$ & $\mathrm{AC}$ & $\mathrm{D}$ \\
\hline & 2005 & DWeA6 & ALD & (?) & $\mathrm{D}$ \\
\hline & & DWeC8 & ALD & (?) & D \\
\hline & & DWeC9 & ALD & (?) & D \\
\hline & & DWeC10 & ALD & (?) & $\mathrm{D}$ \\
\hline & & MagA1 & ACD & $\mathrm{AC}+\mathrm{VL}$ & $\mathrm{D}$ \\
\hline & & MagA6 & ALD & (?) & $\mathrm{D}$ \\
\hline & & MagC5 & ACD & $\mathrm{AC}$ & D \\
\hline & & MagC7 & ALD & (?) & $\mathrm{D}$ \\
\hline & & MagD5 & - & (?) & $\mathrm{D}$ \\
\hline & & MagD8 & ALD & (?) & $\mathrm{D}$ \\
\hline & & MagF6 & ACD & $\mathrm{AC}$ & $\mathrm{D}$ \\
\hline & & MagF9 & ALD & (?) & D \\
\hline \multirow{13}{*}{$\begin{array}{l}\text { Yellow strips } \\
\text { (mostly plants } \\
\text { with rhizomania) }\end{array}$} & & & & & \\
\hline & 2003 & $\begin{array}{l}\text { R156B3 } \\
\text { R156B6 }\end{array}$ & $\begin{array}{l}\text { VLE } \\
\text { ACD }\end{array}$ & $\begin{array}{l}\text { VL } \\
\text { AC }\end{array}$ & $\begin{array}{l}E \\
D\end{array}$ \\
\hline & & VB7 & - & VL & E \\
\hline & & VE2 & - & (?) & D \\
\hline & & VE8 & - & VL & $\mathrm{E}$ \\
\hline & 2005 & DWeB7 & VLE & VL & $\mathrm{E}$ \\
\hline & & DWeE4 & VLE & VL & $\mathrm{E}$ \\
\hline & & DWeE6 & VLE & VL & $\mathrm{E}$ \\
\hline & & DWeE8 & VLE & VL & $\mathrm{E}$ \\
\hline & & MagB1 & VLE & VL & E \\
\hline & & MagB7 & VLE & VL & E \\
\hline & & MagE5 & VLE & VL & E \\
\hline & & MagE6 & VLE & VL & E \\
\hline Transition zone & 2003 & R158C9 & VLD & VL & $D+E$ \\
\hline
\end{tabular}

a Amino acid motifs at $67-68$ and 135 positions were determined by DNA sequencing. All sequenced isolates and some isolates that were not sequenced (-) were included in the allelic discrimination assays.

b Amino acid predictions of the real-time RT-PCR allelic discrimination assays were determined at two polymorphic sites of $\mathrm{p} 25$. Probes that perfectly annealed to the codons encoding the $\mathrm{A}_{67} \mathrm{C}_{68} \mathrm{D}_{135}$ or $\mathrm{V}_{67} \mathrm{~L}_{68} \mathrm{E}_{135}$ motifs gave a positive reaction. A mismatch at any site, such as those that encoded the $\mathrm{A}_{67} \mathrm{~L}_{68}$ motif instead of the $\mathrm{A}_{67} \mathrm{C}_{68}$ motif, resulted in an undetermined (?) call. discrimination to possess the $\mathrm{RB} \mathrm{V}_{67} \mathrm{~L}_{68} \mathrm{E}_{135}$ motif. The rest of these isolates encoded the WT $\mathrm{A}_{67} \mathrm{~L}_{68} \mathrm{D}_{135}$ or $\mathrm{A}_{67} \mathrm{C}_{68} \mathrm{D}_{135}$ motifs. The former was the most commonly found WT p25 signature. It is important to understand that because the WT Taqman probe targeting the 67-68 codons was specific for the $\mathrm{A}_{67} \mathrm{C}_{68}$ allele, none of the WT isolates carrying exclusively the alternative $\mathrm{A}_{67} \mathrm{~L}_{68}$ allele were detectable, and consequently the allelic discrimination assay gave an undetermined call in these cases. Interestingly, allelic discrimination assays also allowed detection of mixed infections through any one of the two targeted polymorphic sites. This occurred with three isolates: two collected from the green areas (R158D6 and MagA1) and one, R158C9, collected from a transitional zone between a symptomatic strip and the adjacent asymptomatic area. Based on the combined results of these assays, R158D6 was expected to be composed of $\mathrm{A}_{67} \mathrm{~L}_{68} \mathrm{D}_{135}+\mathrm{V}_{67} \mathrm{~L}_{68} \mathrm{D}_{135}+\mathrm{V}_{67} \mathrm{~L}_{68} \mathrm{E}_{135}$ genotypes, MagA1 of $\mathrm{A}_{67} \mathrm{C}_{68} \mathrm{D}_{135}+\mathrm{V}_{67} \mathrm{~L}_{68} \mathrm{D}_{135}$, and R158C9 of $\mathrm{V}_{67} \mathrm{~L}_{68} \mathrm{E}_{135}+\mathrm{V}_{67} \mathrm{~L}_{68} \mathrm{D}_{135}$.

Verification of mixed infections. The isolates R158D6, MagA1, and R158C9, detected by the allelic discrimination assay as heterozygous in at least one of its polymorphic sites, and isolates MagB1 and MagF6, considered homozygous for RB and WT, respectively, were analyzed in relation to their genetic composition by cloning the derived high-fidelity amplicons and sequencing a certain number of clones. MagA1, heterozygous for the codons 67-68, was in fact composed of $80 \%$ (16 out of 20 clones) particles carrying the $\mathrm{A}_{67} \mathrm{~L}_{68} \mathrm{D}_{135}$ motif and the rest encoding the $\mathrm{A}_{67} \mathrm{C}_{68} \mathrm{D}_{135}$ motif (Fig. 2). Surprisingly, none of the 20 sequenced clones revealed the expected $\mathrm{V}_{67} \mathrm{~L}_{68} \mathrm{D}_{135}$ motif. In the case of $\mathrm{R} 158 \mathrm{C} 9$, four out of eight clones encoded the WT, $\mathrm{A}_{67} \mathrm{~L}_{68} \mathrm{D}_{135}$, or the RB, $\mathrm{V}_{67} \mathrm{~L}_{68} \mathrm{E}_{135}$, motif. The suspected $\mathrm{V}_{67} \mathrm{~L}_{68} \mathrm{D}_{135}$ genotype was not detected. This isolate exhibited a high degree of sequence variability, in that none of the eight sequenced clones was identical to one another. The R158D6 isolate (10 sequenced clones) was composed of $90 \% \quad \mathrm{~A}_{67} \mathrm{~L}_{68} \mathrm{D}_{135}$ and $10 \% \quad \mathrm{~V}_{67} \mathrm{~L}_{68} \mathrm{D}_{135}$ p25 genotypes. The expected motif encoding glutamic acid (E) at codon position 135 was not detected following this approach. The 11 sequenced clones from the WT control, MagB1, and 10 clones from the RB control, MagF6, exhibited a low degree of genetic variability and were uniformly homozygous for their distinctive amino acid motif.

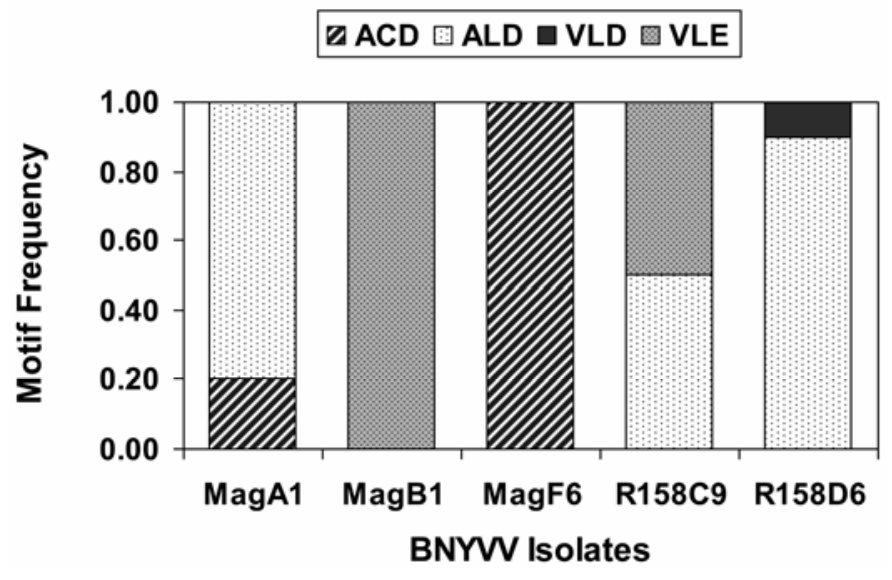

Fig. 2. Frequency of Beet necrotic yellow vein virus haplotypes encoding specific amino acid motifs in the p 25 cistron. They were estimated by cloning the amplicons derived from single-plant infecting populations and DNA sequencing between 8 and 20 individual clones per isolate. The isolates MagA1, R158C9, and R158D6 were considered mix infections according to real-time reverse transcription-polymerase chain reaction allelic discrimination assays. MagB1 and MagF6 were included as resistance-breaking and wild type controls, respectively. 


\section{DISCUSSION}

Analysis of the relationship between virus genotype and host disease response is crucial for the understanding and management of viral diseases. In this work, we found a strong association between specific natural mutations in the p25 cistron of BNYVV RNA 3 and the virus capability to cause rhizomania in previously resistant cultivars of sugar beets. Thus, isolates collected from asymptomatic-resistant or rhizomania-susceptible plants, and most isolates baited from the rhizosphere of asymptomatic-resistant plants (green areas), possessed the $\mathrm{A}_{67} \mathrm{D}_{135}$ motif. On the other hand, all isolates infecting symptomatic $R z 1$ plants encoded the $\mathrm{V}_{67} \mathrm{E}_{135}$ motif. However, this distinction has not held up in other U.S. sugar beet production regions. For instance, preliminary analysis of BNYVV isolates from Minnesota has revealed the WT $\mathrm{A}_{67} \mathrm{D}_{135}$ motif in $R z 1$ cultivars exhibiting severe disease $(20,21)$. Although this observation minimizes the possibility that the $\mathrm{V}_{67} \mathrm{E}_{135}$ motif in p25 is the actual determinant for $\mathrm{RB}$, it also suggests that there might be more than one evolutionary pathway to overcome $R z l$-mediated resistance with its own viral determinant. Alternatively, WT BNYVV without any explicit mutation might overcome resistance just under certain conditions (i.e., high inoculum density, high soil moisture, interaction with another soilborne pathogen, etc.).

In the United States, the association between specific BNYVV p25 motifs and the breakdown of $R z l$ has been observed only in isolates from California. However, a similar situation may be occurring in Spain where RB has been reported (22), and our analysis of a Spanish isolate (accession no. AY696169) revealed that it also encodes the $\mathrm{V}_{67} \mathrm{E}_{135}$ motif. The polymorphism at position 67-68 of p25 has been previously associated with a resistance response in $B$. vulgaris spp. maritima, which might be similarly mediated by $R z l$ (5). Our findings support that observation and indicate that the amino acid at codon 135 might also play a role in overcoming $R z l$-mediated resistance. Thus, this study provides more detailed directions for further reverse genetics experiments designed to understand viral gene functions during pathogenesis. To date, most viral determinants for overcoming specific dominant R-genes correspond to motifs of the coat protein, movement protein, or the replicase complex $(9,12)$. In these plant-virus interactions, the WT viral motifs generally operate as elicitors of plant defense responses. The BNYVV p25 is a major determinant for rhizomania expression (25) and considering that the role of p25 during pathogenesis is still uncertain, investigation of the p25-Rzl association might be an opportunity to discover new properties of viral genes.

A technological advance incorporated in this research was the use of allelic discriminating Taqman probes during real-time RTPCR detection (16). This same technology has been used previously to differentiate isolates of Varicella-zoster virus (2) and Potato virus $Y$ (11). In our case, two pairs of probes were designed to target separate polymorphic sites of the p25 cistron and both were able to provide a clear and accurate call of the detected viral sequences. Moreover, the assay allowed detection of mixed infections, which cannot be evidenced by consensus DNA sequencing. It is important to consider that the probes designed to detect the nucleotide polymorphism at codons 67-68 were specific for the WT GCU UGU sequence or the RB GUU CUU sequence (Table 2). Any other variation in these sequences, like the ones encoding the $\mathrm{A}_{67} \mathrm{~L}_{68}$ or $\mathrm{V}_{67} \mathrm{C}_{68}$ motifs, was consequently undetectable. For this reason, the virus populations R158C9 (ALD plus VLE) and R158D6 (ALD plus VLD) produced a call just for the RB allele instead of a heterozygous call (Table 3). Therefore, an improvement in the resolution of this technique could be the incorporation of more than two allele-specific probes in the same reaction.

Another interesting result from this study was obtained with the MagA1 isolate, which consistently predicted a mixed infection at positions 67-68. However, after DNA sequencing of 20 individual cDNA clones, only variants with the WT $\mathrm{A}_{67} \mathrm{~L}_{68}$ or $\mathrm{A}_{67} \mathrm{C}_{68}$ motif were detected and none with the expected $\mathrm{RB} \mathrm{V}_{67} \mathrm{~L}_{68}$ motif. A similar situation occurred with isolate R158D6 at position 135 where allelic discrimination analysis predicted an $\mathrm{RB}_{135}$ substitution but only the WT $\mathrm{D}_{135}$ was detected. In both cases, haplotypes with the RB motif were probably present in very low numbers and most likely a large number of clones would need to be sequenced before particles with the expected motif are revealed. This scenario is possible considering the high sensitivity attained by real-time RT-PCR. For instance, this technology has the capability to detect as low as 40 virus particles extracted from a viruliferous aphid (17). In the same way, other researchers have found that this technology can easily detected one RB genotype per 1,000 WT genotypes (4), which is comparable to results obtained in our studies (data not shown). Obviously these levels of sensitivity cannot be verified practically by DNA sequencing of individual clones.

The spatial distribution of $\mathrm{RB}$ isolates corresponded to the localization of yellow strips in the field and consequently the spread of rhizomania in $R z 1$ cultivars. On the other hand, the virus genotype baited from the surrounding green areas was predominantly WT $\left(\mathrm{A}_{67} \mathrm{D}_{135}\right)$. Interestingly, WT BNYVV has been consistently isolated from asymptomatic plants during 2006 (data not shown) and basically from any green area sampled from several fields during 2003 and 2005 in this study. The frequency at which WT BNYVV has been isolated from asymptomatic plants indicates that BNYVV is extremely widespread in many infested sugar beet fields and multiplies in the root system of the plants without causing obvious damage. This asymptomatic infection might be due to limited virus accumulation in $R z 1$ cultivars $(10,28)$. Therefore, the biological criterion to differentiate WT from RB isolates is only the capability of the latter to cause severe symptoms of rhizomania in Rzl genotypes. To this condition we have attached the described molecular markers, which will facilitate ecological and evolutionary studies of this plant-virus interaction.

The near exclusive presence of RB haplotypes in the rhizosphere soil from yellow strips suggests that they have gained a fitness advantage over WT isolates under the specific host environment ( $R z l$ cultivars) to which they had been exposed in the field. Also, the occurrence of mixed infections, mainly in the green and transitional areas, revealed that sometimes during development of rhizomania in the field WT and RB haplotypes coexist in the same $R z l$ plant. However, this condition is apparently very unstable and eventually the $\mathrm{RB}$ haplotype gains dominance. A plausible scenario is that RB haplotypes, once derived from the WT genomes by random point mutations, isolate from the parental virus, first, by colonizing some root cells and then by a bottleneck event during vector transmission. A similar evolutionary strategy has already been described for sympatric populations of Wheat streak mosaic virus (8). The almost complete exclusion of WT isolates from the yellow strips suggests that over time RB isolates likely will become the dominant haplotype in the field. Therefore, sources of resistance to BNYVV other than Rzl need to be incorporated in order to maintain a viable sugar beet industry.

\section{ACKNOWLEDGMENTS}

We thank B. Bryan for her technical support, I. Torres-Jerez for her technical counseling, and F. Workneh and R. Lewellen for their theoretical contributions during the preparation of this manuscript. A portion of this work was funded by grants from the Beet Sugar Development Foundation and the Minnesota and North Dakota Research and Education Board. 


\section{LITERATURE CITED}

1. Afonina, I., Zivarts, M. Kutyavin, I., Lukhtanov, E., Gamber, H., and Meyer, R. B. 1997. Efficient priming of PCR with short oligonucleotides conjugated to a minor groove binder. Nucleic Acids Res. 25:2657-2660.

2. Campsall, P. A., Au, N. H. C., Prendiville, J. S., Speert, D. P., Tan, R. S., and Thomas, E. E. 2004. Detection and genotyping of Varicella-zoster virus by TaqMan allelic discrimination real-time PCR. J. Clin. Microbiol. 42:1409-1413.

3. Canova, A. 1958. Appunti de patologia della barbabietola. Inform. Fitopatol. 9:390-396.

4. Capote, N., Gorris, M. T., Martinez, M. C., Asensio, M., Olmos, A., and Cambra, M. 2006. Interference between D and M types of Plum pox virus in Japanese plum assessed by specific monoclonal antibodies and quantitative real-time reverse transcription-polymerase chain reaction. Phytopathology 96:320-325.

5. Chiba, S., Miyanishi, M., Kondo, H., and Tamada, T. 2002. Single amino acid changes in the 25 protein of Beet necrotic yellow vein virus determinate resistance responses of Beta vulgaris spp. maritima. Pages 58 in: Proc. Fifth Symposium of the International Working Group on Plant Viruses with Fungal Vectors. C. Rush and U. Merz, eds. ASSBT, Zurich, Switzerland.

6. Dubois, F., Sangwan, R. S., and Sangwan-Norreel, B. S. 1994. Spread of Beet necrotic yellow vein virus in infected seedlings and plants of sugar beet (Beta vulgaris). Protoplasma 179:72-82.

7. Duffus, J. E., Whitney, E. D., Larsen, R. C., Liu, H.-Y., and Lewellen, R. T. 1984. First report in Western hemisphere of rhizomania of sugar beet caused by Beet necrotic yellow vein virus. Plant Dis. 68:251.

8. Hall, J. S., French, R., Hein, G. L., Morris, T. J., and Stenger, D. C. 2001. Three distinct mechanisms facilitate genetic isolation of sympatric Wheat streak mosaic virus lineages. Virology 282:230-236.

9. Harrison, B. D. 2002. Virus variation in relation to resistance-breaking in plants. Euphytica 124:181-192.

10. Heijbroek, W., Musters, P. M. S., and Schoone, A. H. L. 1999. Variation in pathogenicity and multiplication of Beet necrotic yellow vein virus (BNYVV) in relation to the resistance of sugar-beet cultivars. Eur. J. Plant Pathol. 105:397-405

11. Jacquot, E., Tribodet, M., Croizat, F., Balme-Sinibaldi, V., and Kerlan, C. 2005. A single nucleotide polymorphism-based technique for specific characterization of $\mathrm{Y}^{\mathrm{O}}$ and $\mathrm{Y}^{\mathrm{N}}$ isolates of Potato virus $Y$ (PVY). J. Virol. Methods 125:83-93.

12. Kang, B.-C., Yeam, I., and Jahn, M. M. 2005. Genetic of plant virus resistance. Annu. Rev. Phytopathol. 43:581-621.

13. Kaufmann, A., Koenig, R., and Lesemann, D.-E. 1992. Tissue printimmunoblotting reveals an uneven distribution of beet necrotic yellow vein and beet soil-borne viruses in sugar beets. Arch. Virol. 126:329-335.

14. Lauber, E., Guilley, H., Tamada, T., Richards, K. E., and Jonard, G. 1998. Vascular movement of Beet necrotic yellow vein virus in Beta marcro- carpa is probably dependent on an RNA-3 sequence domain rather than a gene product. J. Gen. Virol. 79:385-393.

15. Liu, H.-Y., Sears, J. L., and Lewellen, R. T. 2005. Occurrence of resistance-breaking Beet necrotic yellow vein virus of sugar beet. Plant Dis. 89:464-468.

16. Livak, K. J. 1999. Allelic discrimination using fluorogenic probes and the 5 ' nuclease assay. Genet. Anal.-Biomol. E. 14:143-149.

17. Olmos, A., Bertolini, E., Gil, M., and Cambra, M. 2005. Real-time assay for quantitative detection of non-persistently transmitted Plum pox virus RNA targets in single aphids. J. Virol. Methods 128:151-155.

18. Richards, K., and Tamada, T. 1992. Mapping functions on the multipartite genome of Beet necrotic yellow vein virus. Annu. Rev. Phytopathol. 30:291-313.

19. Rush, C. M. 2003. Ecology and epidemiology of benyviruses and plasmodiophorid vectors. Annu. Rev. Phytopathol. 41:567-592.

20. Rush, C. M., Liu, H. Y., Lewellen, R. T., and Acosta-Leal, R. 2006. The continuing saga of rhizomania of sugar beets in the United States. Plant Dis. 90:4-6.

21. Rush, C. M., Steddom, K., Jones, D., and Acosta-Leal, R. 2006. Breakdown of $R z 1$ in individual plants of rhizomania tolerant cultivars. Pages 81-84 in: Proc. Sixth Symposium of the International Working Group on Plant Viruses with Fungal Vectors. C. Rush, ed. ASSBT, Denver, CO.

22. Schirmer, A., Link, D., Cognat, V., Moury, B., Beuve, M., Meunier, A., Bragard, C., Gilmer, D., and Lemaire, O. 2005. Phylogenetic analysis of isolates of Beet necrotic yellow vein virus collected worldwide. J. Gen. Virol. 86:2897-2911.

23. Scholten, O. E., Paul, H., Peters, D., Lent, J. W. M., and Goldbach, R. W. 1994. In situ localization of Beet necrotic yellow vein virus (BNYVV) in rootlets of susceptible and resistant beet plants. Arch. Virol. 136:349-361.

24. Tamada, T. 1999. Benyviruses. Pages 154-160 in: Encyclopedia of Virology. R. G. Webster and A. Granoff, eds. Academic Press, London.

25. Tamada, T., Uchino, H., Kusume, T., and Saito, M. 1999. RNA-3 deletion mutants of beet necrotic yellow vein virus do not cause rhizomania disease in sugar beets. Phytopathology 89:1000-1006.

26. Verchot-Lubicz, J. 2003. Soilborne viruses: Advances in virus movement, virus induced gene silencing, and engineered resistance. Physiol. Mol. Plant Pathol. 62:55-63.

27. Vetter, G., Hily, J. M., Klein, E., Schmidlin, L., Haas, M., Merkle, T., and Gilmer, D. 2004. Nucleo-cytoplasmic shuttling of the beet necrotic yellow vein virus RNA-3-encoded p25 protein. J. Gen. Virol. 85:2459-2469.

28. Wisler, G. C., Lewellen, R. T., Sears, J. L., Liu, H.-Y., and Duffus, J. E. 1999. Specificity of TAS-ELISA for Beet necrotic yellow vein virus and its application for determining rhizomania resistance in field-grown sugar beets. Plant Dis. 83:864-870.

29. Workneh, F., Villanueva, E., Steddom, K., and Rush, C. M. 2003. Spatial association and distribution of Beet necrotic yellow vein virus and Beet soilborne mosaic virus in sugar beet field. Plant Dis. 87:707711. 